PARTICULAR ISSUES OF PHILOSOPHY

DOI: 10.46340/ephd.2021.7.2.8

Andrii Semenov, PhD in Philosophy

ORCID ID: https://orcid.org/0000-0001-5082-4620

Lesya Ukrainka Volyn National University, Ukraine

\title{
GLOBAL CHALLENGES TO THE PHILOSOPHY OF THE FUTURE
}

\author{
Андрій Семенов, к. ф. н. \\ Волинський національний університет імені Лесі Українки, Україна
}

\section{ГЛОБАЛЬНІ ВИКЛИКИ ДО ФІЛОСОФІЇ МАЙБУТНЬОГО}

The article reveals the significant issues of modern philosophy and fundamental aspects and challenges to the philosophy of the future. The relevance of the article is stipulated by the nature and content of global social dynamics in the third millennium and the certain vital and problematic issues of philosophical understanding of the present and philosophical education of the future. The relationship between the nature of civilization's social development, the guidelines of philosophical discourse and perspective is of particular significance. The paper uses statistical data and analytical description of the annual UN reports "Human Development Report», where it is noted that overcoming unidimensionality and mechanicalism is problematic and progressive in modern philosophy. It requires an understanding of new universals of human existence, where the formula of global human existence is one of the most significant. The philosophy of the future is considered as a philosophy of world integration and philosophy of humanism, socially-oriented to the world practice of free human self-determination, recognition of the human rights, and the prolongation of social responsibility and ethics. The issue of anthroposocial modeling and philosophical prognoseology are the key aspects of philosophical education development.

Problems of Humanism and World Integration are a research topic that emphasizes the importance of social modeling of processes, explanation of the principle of civic humanism, and world integration. The issue is regarded from the point of view of interdisciplinary analysis and modeling. This aspect has not been highlighted in such scientific branches as political science, social philosophy, international relations, and mathematical modeling. Therefore, the subject matter of the research is Globalization and Humanization of Social Systems and Social Relations in the 21st Century.

Keywords: global community, civilization, social dynamics, philosophy, philosophical anthropology, philosophical education, social and humanitarian, modeling, anthroposocial modeling, philosophical prognoseology.

«Філософія по суті несвоєчасна, належить до тих небагатьох речей, доля яких - ніколи не отримати відгомін у змінному «сьогодні», та й ніколи не наважитись на це. Там, де це відбувається, де філософія стає модою, там або ж немає істинної філософії, або ж вона витлумачується фальшиво і використовується для якихось чужих їй цілей повсякденності» ${ }^{1}$.

1. Чому і про що мовчить філософія ?

«Філософія завжди є не співзвучною часу, а навпаки, задає часу свої виміри» - ці відомі слова видатного німецького філософа М. Хайдеггера, вимовлені у середині ХХ ст., зберігають актуальність щодо сутності та змісту субстанційності філософії і у наш час. Традиційне витлумачення двох головних історичних форм панування філософії- філософії як академічної університетської

${ }^{1}$ Хайдеггер, М. (1992). Введение в метафизику. Киев: Новый круг, 95. 
дисципліни та філософії як способу світосприйняття і світовідношення певною мірою окреслило і дихотомію співіснування та розвитку таких форм. Парадокс, але введення філософії з часів ранніх середньовічних університетів у класичний контекст університетського освітнього модуля завдало чимало питань щодо живого та гнучкого характеру самої філософії.

По-перше, з огляду на «академізм» освіти від епохи раннього Модерну до середини XX ст, філософський дискурс в головному був зведений до апріорно лінійного, здебільш наукового обгрунтування феноменів буття. Вже у передмові до «Феноменології духу» Г. Гегель писав: «Моїм наміром було сприяти наближенню філософії до форми науки - до тієї мети, досягнувши якої, вона могла б відмовитись від свого імені любові до знання і бути дійсно знанням. Внутрішня необхідність того, щоб знання було наукою, полягає у його природі і задовільне пояснення цьому дається тільки у викладі самої філософії» ${ }^{1}$ А на світанку XX ст. Е. Гуссерль зазначив, що «Із самого початку свого виникнення філософія виступала 3 домаганням бути строгою наукою і при цьому такою, що задовольняла б найвищі теоретичні потреби, і в етично-релігійному відношенні робила б можливою життя, що керувалось би чистими нормами розуму. Це домагання поставало то з більшою, то 3 меншою енергією, але ніколи не зникало...»².

По-друге, позиціонування філософії як першооснови, онтологічно-засадничої гуманітарної практики щодо усіх форм та феноменів буття дозволило їй у запитувати з приводу самих запитань у самої себе, тобто метафілософствувати. В роботі «Шляхи до співбесіди» М. Хайдеггер сформулював це у наступний спосіб: «Філософію переоцінюють, очікуючи від неї безпосередньої користі. Філософію недооцінюють, знаходячи у ній, але лише у «абстрактному»... вигляді, все те ж саме, те, у чому і без того встигло цілком чуттєво переконатись на досвіді наше спілкування з речами. Проте істино філософське знання ніколи не буває якоюсь запізнілою добавкою гранично всезагальних уявлень до вже існуючого сущого... ${ }^{3}$.

Трансформація фундаменталізму у класичній ортодоксальній метафізично-онтологічній філософській парадигмі, яка мала місце наприкінці епохи модерну, викликала до життя нові (хоча доволі часто неапробовані та непідтверджені) напрямки та обрії філософського дискурсу. Гуссерлівське прагнення «чистої філософії», себто «чистої свідомості», через століття змінюється новим гаслом - «наблизити філософію до практики!» Це гасло, проголошене в епоху третьої глобальної світоглядної революції (80-90 pp. XX ст. - початок 00-х років XXI ст.) видавалось певним прагматичним постулатом конструювання нової філософії. Що власне окреслив цей девіз? I чи виявилось це під силу - створити постмодерний синкретичний, чи швидше інтегративний модуль релігії, філософії, науки та практики? Певна латентність висновків та відповідей на ці питання прихована у сприйнятті, розумінні, витлумаченні та трансформації самого поняття та смислоутворення «сучасна філософія».

При визначеній доступності і навіть можливості експлікації сучасної гуманітарної науки в їі стандартно диференційованих дисциплінах - «сучасна соціологія, психологія, релігієзнавство», «новітня історія чи ж історія Новітнього часу»,- питання щодо сучасної філософії є значно складнішим, оскільки потребує розуміння та характеристики сучасного мислення, сучасного світорозуміння та світовідношення, принципів та властивостей філософського самоаналізу у новому транскордонному, гіпердинамічному світі. У більшості наукових програм, в університетській освіті досить «обережно», навіть «сором'язливо» йдеться за сучасну філософію. Радше зустрічається контекст філософії 20 ст., або ж, у кращому випадку, другої половини 20ст., яка чомусь витлумачується як сучасна. Філософія сьогодення (вона ж сучасна філософія) - це передусім та система інтегративного та інтерактивного осмислення дійсності, яка відтворює «дух та поступ» теперішності: іншими словами - та філософія, яка співзвучна нам у просторі і часі. I це аж ніяк не філософія початку, середини чи навіть кінця 20 ст. Світ - транскордонний, гіпердинамічний, багатовимірний та полівекторний. Ми живемо у феноменальну епоху феноменальних парадоксів: розробили і втілюємо технології майбутнього не маючи відповідей (можливості вийти 3 формату кантівської трансцендентності) щодо фундаментальних засад свого минулого. Жодна 3 концепцій світотворення не є на даний час аксіомою, відповідно не може бути ні предистинацією, ні похідною

\footnotetext{
${ }^{1}$ Гегель, Г. В. Ф. (2000). Феноменология духа. Москва: Наука, 10.

${ }^{2}$ Гуссерль, Э. (2000). Логические исследования. Картезианские размышления. Кризис европейских наук и трансиендентальная феноменология. Кризис европейского человечества и философии. Философия как строгая наука. Москва: АСТ, 669.

${ }^{3}$ Хайдеггер, М. (1993). Работы и размыєиления разных лет. Москва: Гнозис, 324.
} 
для моделі світотворення. Новітня історія цивілізації виокремила і відповідну об'ємну площину новітніх антропосоціальних питань та проблем. Цивілізаційний простір і час, який видавався (та й радше витлумачився як константа), зазнав видозмін як у сутнісному, так і в оціночному аспектах, свідченням чого $€$ :

- інтеграція та реінтеграція спільнот та кордонів (від видозміни Старого світу та утворення ЄС до деколонізації та неконтрольованих економічних, політичних, релігійних внутрішніх та зовнішніх міграцій)

- трансформація світу як системи (від руйнування біполярності та дихотомічності світових систем до нової геополітичної карти світу, утворення новітніх економіко-політичних, військових та територіальних об'єднань)

- сутнісна та оціночна видозміна часу історії та цивілізацій (від еволюційно-ієрархічних моделей світоустрою до нелінійних феноменів порядку та хаосу, синергетики тощо)

- гіпердинаміка та транскордонність сучасного світу (від моновимірності та лінійності простору і часу до феноменів інформаційної та постінформаційної цивілізаціі, співіснування світоглядних та інструментальних цінностей)

- тотальна взаємоприсутність та взаємодоповнюваність фундаментально різних форм людського буття, свідомості та культури (релігія, філософія, наука, практика). Власне це і окреслив у своїй роботі «21 урок для 21 століття» Ювал Харарі : «Людство втрачає віру в ліберальну оповідь, що домінувала в глобальній політиці впродовж останніх десятиліть, саме тоді, коли поєднання біо- й інформаційних технологій висуває нам найбільші виклики, 3 якими людство стикалось будь-коли» ${ }^{1}$.

\section{2. Обрії та перспективи філософії майбутнього}

3 огляду на вищевикладене, можливо сформулювати перелік питань до тієї парадигми філософії, яку ми можемо спробувати змоделювати, а саме: чи є трансцендентність філософії є однією з найважливіших ознак iї дієвості та дійсності? Чи існує потреба у кардинальній реконструкції академічної філософської традиції і чи потрібно взагалі намагатись «корегувати» філософську думку, філософські напрямки та її предметність? Яке співвідношення гармонійно з'єднає класичний курс метафізики та філософію техніки і технологій, онтологію та філософську глобалістику, гносеологію та біофілософію, етику геномних досліджень та етику соціальної відповідальності? Зрештою, чи можливо позиціонувати філософію гуманізму як філософію світової інтеграції $\mathrm{i}$ який антропосоціальний вимір сучасної прагматичної філософії? Чимале коло питань виокремлюється i у відношенні філософської методології та філософії науки, системності та свободи академічної філософії, філософського моделювання та філософської прогностики.

Філософствування сьогодні постає як пошук нових, більш ефективних шляхів інтерпретації, конкретизації абстрактних уявлень, понять, як передумова відходу від спроб прямої екстраполяції складеного раніше знання на нові явища. Філософствування як форма руху в сфері всезагального не може вирішувати завдання синтезу, пошуку його міри, не конкретизуючи результати свого дослідження, не залучаючи до цього процесу інші науки, які насамперед мають своїм предметом сферу людської реальності. Філософії взагалі, як і філософії сьогодення, зокрема, не властиво і не може бути властиво ідейне, соціальне обгрунтування як керівництво до дії, їй не притаманні абсолютистські формули соціальної прагматики і утопії. I все ж саме за нею зберігається місце континуальної і водночас партикулярної традиції руху, світопереживання і світоосягнення, площини співпіставлення і сумніву, раціонального і ірраціонального. Сучасна філософія намагається втримати та відтворити фундаментальні, глибинні засади антропного принципу. Ще в середині XX ст. Мішель Фуко в роботі «Слова і речі» відзначив: «Той спосіб у який людина утвердилася в сучасній думці, дозволяє їй грати дві ролі: вона водночас лягає в основу всіх позитивностей і присутня-хоч не можна сказати, що вона там у привілейованому становищі, - у складі всіх емпіричних речей...» ${ }^{2}$. Водночас людина, як складна система суб'єкт-об'єктної приналежності до світу, як передумова і водночас похідна світотворчості залишається одним з найбільш змістовних об'єктів філософської рефлексії. Проте ще на світанку «філософії життя» Фрідріх Ніцше в роботі «Людське, занадто людське» застерігав: «Всі філософи мають той загальний недолік, що вони виходять з сучасної людини i намагаються дістатись до мети за допомогою аналізу останньої. Мимовільно перед ними постає

\footnotetext{
${ }^{1}$ Харарі, Ю. Н. (2018). 21 урок для 21 століття. Київ: Форс Україна, 17.

2 Рюс, Ж. (1998). Поступ сучасних ідей: Панорама новітньої науки. Київ: Основи, 492.
} 
«людина» взагалі, як деяка aeterna veritas, як незмінне у загальному потоці, як надійне мірило речей. Проте все, що філософ висловлює про людину, є, по суті, не чим іншим, як свідченням про людину досить обмеженого проміжку часу...» ${ }^{1}$.

Воднораз теперішне аж ніяк не можна розглядати лише крізь призму історичного минулого, віддаленого історичного досвіду, соціокультурного простору і часу. Світ набуває новітніх нелінійних, синергетичних ознак трансформації і видозмінюється значно швидше (у певних сферах в геометричній прогресії), аніж ми про це мислимо та дискутуємо. Глобальні виклики до життя, та, відповідно, глобальні виклики до філософії майбутнього детерміновані власне трансформованим, транскордонним та гіпердинамічним світом сучасної людини. Феномени «глобального мислення», «глобальних стратегій», «геополітики» екстраполюють раніше складені смисли та сенси на новітні форми, формули та стилі життєпроявів та життєтворчості.

Філософія сьогодення, себто сучасна філософія, з одного боку, є паритетною формулою наукових систем новітньої історії, з іншого - гіпотетичним пріоритетом сучасної соціальної прагматики. У сучасній філософії спостерігається тенденція до багатовимірності суб'єкта - об'єкта філософського аналізу та дискурсу, до відходу від витлумачення функції філософії як методу опису, експлікації та надання дефініцій явищам, процесам і станам. Безсумнівно, трансформація глобального суспільства була обумовлена (та й, у свою чергу, обумовлювала) необхідністю нової методології дослідження людської реальності, яка була б відмінна від методології редукції суспільства до особистості та від редукції особистості до любих форм цілого. Більше того, ось уже упродовж трьох десятиліть новітньої геополітичної історії філософська думка, філософська рефлексія видається чи не єдиним зусиллям інтегративного, інтерактивного та транскордонного світотворення людини. Світотворення, яке «підживлює» людину феноменами духовного світоосягнення: вірою, надією, любов'ю. Саме ці феномени буття людини, духовні вправи, як вдало відзначив П'ер Адо в «Духовних вправах і античній філософії», призводять до «трансформації світобачення і до перетворення особистості... Ці вправи є творінням не тільки думки, а й усієї психіки індивіда...»². Процес такого світоосягнення протікає в різних площинах самовизначення людини: від ідентифікації особистості до складних систем моделювання фізичної і антропосоціальної реальності, від конструювання власного «Я» до переосмислення та переформатування того, що складає власне «людське» у людині. Сферою аналізу стають не абстрактні моральні ідоли і ідеали, а те, як сучасна людина самовизначається у соціо- і техногенному світі, де сам світ видається не єдиною компіляцією уявлень про нього, а змістовно диференціюється на світ речей, явищ, подій, природи, техніки, культури, Божественний світ і т.п.

\section{3. Філософія гуманізму як філософія світової інтеграції}

Запитувальний характер філософії - це не лише спроба ідентифікувати площину чи виміри неосяжного, окреслену М. Хайдеггером у фундаментальній світожиттєвій парадигмі у «Вступі до метафізики»: «Чому $є$ все суще, а не, навпаки, ніщо»? З3 Запитувальний характер філософії - це також спроба структурувати та впорядкувати еклектичність сучасного світу людини, її типологію світовідношення та свободопрояви, оскільки за влучним виразом Леоніда Столовича «Філософія - як феномен культури... - драма з усе більшим числом діючих осіб, і нескінченна унікальність кожного філософа розкривається і має філософський смисл тільки в одночасності та у взаєморозумінні філософських систем, ідей, одкровень» ${ }^{4}$.

Сучасний світ, як ніколи, вимагає подолання моновимірності, механицизму і закликає до осмислення нових універсалій людського існування, де однією з найважливіших є формула глобального гуманістичного буття людини. Ще у 1974 році академік А.Сахаров у статті «Світ через півстоліття» писав, що одним з найбільш актуальних «надзавдань» $є$ завдання здолати суперечності та диспропорції у загальноантропологічній, цивілізаційній перспективі. «Я вірю, що людство віднайде розумне рішення складного завдання здійснення величезного, необхідного і невідворотнього прогресу із збереженням людського в людині та природного в природі» ${ }^{5}$. На рівні глобального

\footnotetext{
${ }^{1}$ Ницше, Ф. (1990). Сочинения в 2 томах. Москва: Мысль, 1, 240.

${ }^{2}$ Рюс, Ж. (1998). Поступ сучасних ідей: Панорама новітньої науки. Київ: Основи, 544.

${ }^{3}$ Хайдеггер, М. (1992). Введение в метафизику. Киев: Новый круг, 95.

${ }^{4}$ Столович, Л. Н. (2000). Вопросы философии. О «системном плюрализме» в философии, 9, 47.

${ }^{5}$ Сахаров, А. (1990). Мир, прогресс, права человека: Статьи и выступления. Ленинград: Советский писатель, 49.
} 
суспільства, у щорічній доповіді ООН про розвиток людини «Human Development Report» тема глобальних видозмін та відповідних трансформацій життя людини є однією з найбільш вагомих та дискусійних. Зокрема, цьому присвячені доповіді за 2014 рік «Забезпечення стійкого прогресу людства зменшення вразливості та формування життєстійкості», 2015 рік «Праця задля людського розвитку», 2016 рік «Людський розвиток для усіх і для кожного», 2018 рік «Індекси та індикатори людського розвитку. Оновленні статистичні дані за 2018 рік», 2019 рік «За кордонами рівня доходів і середніх показників сьогодення: нерівність у людському розвитку у XXI ст» ${ }^{1}$.

Безсумнівною константою цих інформаційно-аналітичних описів $є$ емпіричний матеріал, що складає фундаментальну частину доповідей (зокрема - показник Індексу людського розвитку) і базується на об'єктивних даних статистики та досліджень територій та культур. Однак увагу привертає і власне філософсько-аналітична, категорійна складова доповідей, яка оперує категоріями філософсько-антропологічного та морально-етичного паритету - «гідність», «самовизначення», «достойний рівень життя», «потенціал та можливість для усіх індивідів», «толерантність», «віротерпимість», «рівновеликість», «діалогічність» тощо. Йдеться, власне, за те, що проблеми самоідентифікації, соціальної рівності і рівноваги, внутрішніх джерел розвитку є і пріоритетами гуманістичної антропології, що утримують мобільну систему антропосоціального моделювання та громадянської практики. Людський розвиток, окрім усього - це також розвиток свободи людини в її наявності та перспективі реалізації. I можливо, те, що в структурі академічної філософії особливу значущість набувають прогностичні аспекти філософії людини є своєрідним випереджальним відображенням конструктивізму людини майбутньої як сучасника, людини вільної в своїй власній долі і виборі співпричетному долі людства загалом.

Світ людини надзвичайно тонкий і чутливий, прагматичнний і конкретний, раціональний та ірраціональний водночас. Проте і сама людина є частиною цього світу, а значить, частиною відкритою і незавершеною в майбутньому. Людина не є закінченою істотою, а належить до всіх змін, пов'язаних з законами еволюції. Сьогодні вона не та, що була у минулому, і в майбутньому вона буде не така, як сьогодні. Філософія майбутнього, у своїй метафілософській транскрипції виокремлює запити до людини майбутнього в їі становленні, пошуку, життєтворчості та перспективі. Філософія майбутнього - це усвідомлення відповідальності за історію, теперішнє та прийдешнє, це унікальна можливість пошуку та відтворення нової глобальної гуманістичної формули життя людини, суспільства, цивілізації.

\section{References:}

1. Khaydegger, M. (1992). Vvedenie v metafiziku [What Is Metaphysics]. Kyiv: Novyj krug. [in Russian].

2. Gegel, G. V. F. (2000). Fenomenologiya dukha [The Phenomenology of Spirit]. Moscow: Nauka. [in Russian].

3. Gusserl, E. (2000). Logicheskie issledovaniya. Kartezianskie razmyshleniya. Krizis evropeyskikh nauk $i$ transtsendental'naya fenomenologiya. Krizis evropeyskogo chelovechestva i filosofii. Filosofiya kak strogaya nauka [Logical Studies. Cartesian Reflections. The crisis of the European sciences and transcendental phenomenology. The crisis of European humanity and philosophy. Philosophy as a rigorous science]. Moscow: ACT. [in Russian].

4. Khaydegger, M. (1993). Raboty i razmyshleniya raznykh let [Works and Reflections from Various Years]. Moscow: Gnozis. [in Russian].

5. Kharari, Y. N. (2018). 21 urok dlya 21 stolittya [21 Lessons for the 21st Century]. Kyiv: Fors Ukraina. [in Ukrainian].

6. Ryus, Z. (1998). Postup suchasnikh idey: Panorama novitnoj nauki [The March of Contemporary Ideas: A Panorama of Modernity]. Kyiv: Osnovi. [in Ukrainian].

7. Nitsshe, F. (1990). Sochineniya v 2 tomakh [Essays in 2 vols]. Moscow: Thought, 1. [in Russian].

8. Stolovich, L. N. (2000). $O$ «sistemnom plyuralizme»v filosofii [Questions of Philosophy. Systemic pluralism in philosophy]. Moscow: RAN, 9, 46-56. [in Russian].

9. Sakharov, A. (1990). Mir, progress, prava cheloveka: Stati i vystupleniya [Peace, Progress, Human Rights: Articles and Speeches]. Leningrad: Soviet writer. [in Russian].

\footnotetext{
${ }^{1}$ Human Development Report Office (2020). Human Development Report. United Nations Development Programme. <http://hdr.undp.org/> (2021, April, 01).
} 